\title{
Spatial Analysis and Sustainable-Strategic Environment Management at Baron Spring Catchment Area, Karst of Gunung Sewu, Yogyakarta
}

\author{
Hilary Reinhart ${ }^{1}$, Andi Rifani ${ }^{1}$ \\ ${ }^{1}$ Alumnae Master of Environmental Management, Graduate School, Universitas Gadjah Mada; e-mail: \\ hilary.reinhart@mail.ugm.ac.id, andi.rifani@mail.ugm.ac.id
}

\begin{abstract}
ABSTRAK
Karakteristik utama akuifer pada kawasan Karst Gunung Sewu adalah sistem infiltrasinya yang dominan tersusun atas rekahan-celahan sehingga menimbulkan masalah pencemaran karena buruknya filtrasi. Salah satu sumber air yang ada di kawasan ini adalah Mataair Baron. Mengingat pentingnya Mataair Baron sebagai sumber air bersih, studi ini dilakukan untuk mengetahui pencemaran yang terjadi di Mataair Baron dan aspek-aspek yang mempengaruhinya. Dari kajian tersebut, diharapkan didapatkan rekomendasi pengelolaan lingkungan yang memperhatikan aspek-aspek pembangunan berkelanjutan dan perencanaan ruang yang tepat guna. Dalam mencapai tujuan tersebut, analisis dalam studi ini menggunakan pendekatan keruangan dan hidrologis. .Pendekatan hidrologis dilakukan dengan memeriksa parameter-parameter kualitas cuplikan air pada Mataair Baron dan menghitung indeks pencemaran untuk mengetahui kualitas air dan status pencemaran. Hasil tersebut kemudian dikaji lebih mendalam dengan pendekatan keruangan dengan menggunakan data geomorfologis dan penggunaan lahan untuk kemudian menentukan faktor-faktor yang mempengaruhi kualitas dan status air tersebut. Hasil yang didapat adalah Mataair Baron berada pada status cemar ringan dengan jumlah TSS mencapai 97,1 mg/L, bikarbonat mencapai 96 $\mathrm{mg} / \mathrm{L}$, total koliform $210 \mathrm{MPN} / 100 \mathrm{~mL}$, dan total minyak lemak mencapai $2 \mathrm{mg} / \mathrm{L}$ dan telah melalui bakumutu yang ditetapkan. Angka tersebut berkorelasi dengan penggunaan lahan di sepanjang daerah tangkapan dimana banyak terdapat pemukiman dan lubang-lubang pengatusan. Untuk menanganinya, strategi-strategi pengelolaan yang dilakukan perlu berjalan dalam dua dimensi yakni dimensi sosio-kultural dan dimensi keruangan. Setiap dimensi harus terkait dan tidak dapat dipisahkan satu dengan yang lainnya. Pengelolaan daerah tangkapan juga perlu dilakukan dengan menggandeng seluruh pemangku kepentingan yang ada.
\end{abstract}

Kata Kunc: Mata air Baron; karst; kualitas air;indeks polusi;analisis spasial; gunung sewu

\begin{abstract}
Gunung Sewu's karstic aquifer characteristic of fracture-fissure water conduit leads to pollution problem in the water resources. One main source of water used is the Baron Spring. This study aims to analyze the water quality of the Baron Spring toward the land use in the catchment area and provide recommendations for spatial planning and water management in certain area. This research used spatial analysis of GIS and water quality was analyzed by Pollution Index. The results showed that the Baron Spring was in a mild contaminated state with amount of TSS was $97,1 \mathrm{mg} / \mathrm{L}$, bicarbonate $96 \mathrm{mg} / \mathrm{L}$, total coliform $210 \mathrm{MPN} / 100 \mathrm{ml}$, and total oil and fat $2 \mathrm{mg} / \mathrm{L}$ which have exceeded the water source quality standards. Those results are related with the land use in the catchment area where settlement is dense in the upstream, also because of the distribution of settlement and sinkhole in the middle-part of catchment.In coping with the contamination and pollution several strategies are urged to be designed and implemented. Strategies comprised by two approaches, socio-cultural and spatial approach. Each of the approaches is linked and should not be separated. Management of catchment including stakeholder involvement and spatial planning are essential to be considered.
\end{abstract}

Keywords: baron spring; karst; water quality; pollution index; spatial analysis; gunung sewu

Citation: Reinhard, H., dan Rifani, A. (2019). Spatial Analysis and Sustainable-Strategic Environment Management at Baron Spring Catchment Area, Karst of Gunung Sewu, Yogyakarta. Jurnal Ilmu Lingkungan, 17(2), 341-350, doi:10.14710/jil.17.2.341-350 


\section{Introduction}

Karst landscape is well known for its uniqueness and typical features. Processes and dynamics of this landscape are the main factors which make karst become different among other landscapes. The key process in karst landsacpe is the solution of the limestone. Limestone is relatively soluble compared to other rocks in the world. The dissolution creates mostly surface and subsurface features where water flows through the cracks and fissures all over the karst area (Bonacci, 1987; Milanovic, 2005). It eventually leads to the peculiar and unique hydrological properties which characterized by its aquifer, porosity and permeability, anisotropic and heterogeneity (Haryono \& Adjie, 2004). Complexity of karst area makes it easily affected by human activities (Burri, Castiglioni, Sauro, 1999). Currently, karst supplies $25 \%$ of water needs all over the globe (Ford \& Williams, 2007) and higher precentage in the region with mostly karst area, its water supplies are provided by karst landscape.

Because it mainly comprises by secondary porosity, water which flows in karst is poorly filtered which leads to the main problem of karst hydrology: the pollution of groundwater (Bakalowicz, 2011). Pollutions may come from human activity and land use such as domestic sector, agriculture, or even limestone mining (Naja, Rivero, et al., 2010). Inherently, due to the karstification and souliton process, karst water contains major ions such as Natrium, Magnesium, and Calcium (Perez-Ceballos, Pacheco-Avila, et al., 2011). Those characteristics may lead to the health issue hence it becomes one of the main focuses at karst groundwater preservation and conservation.

It is imperative to comprehend and manage the water issues at karst area. It requires an examination on hydrological response and aquifer in order to comprehend the hydrological characteristics of a particular karst area (Ford, 2003; Kiraly, 2003; Adjie, 2009; Vysoka, Bruthans, Zak, et al., 2011). Through a thorough examination, it can be concluded that hydrological characteristics of karst yield certain vulnerability (Marin, Andreo, \& Mudarra, 2015; Marin, Andreo, Jimenez-Sanchez, 2011; Pratiwi, 2013; Prayogo et al., 2015; $\mathrm{Zhu}$, Wang, $\mathrm{Hu}$, et al., 2019).

Taking water issues in karst also means embracing it on the terms of sustainable development. Point number 6 "Clean Water and Sanitation" of 17 goals at Sustainable Development Goals directly related to the water quality issues at karst area. This paper aims to elaborate the importance and significance of water quality and the factors which induced it. Furthermore, it also examines and develops the notion on how sustainable development is a fundamental concept on karst management, vis a vis on how karst's hydrological conservation is basically an effort toward sustainable development (Van Beynen,
Brinkmann, van Beynen, 2012; Brinkmann \& Parise, 2012).

\section{Methodology}

This aims to analyze and monitor water quality at Baron Spring as one of the main source of water supply. Sampling method to use was purposive sampling where Baron Spring was selected because all of the water in Bribin Underground System flows to this spring. The pollution will be accumulated and can be used to reflect how much the pollution all along the Underground River is.

A. Spatial Analysis

Spatial analysis was used to help understand the factors which affect the water quality holistically. From the spatial analysis, it can be known what kind of human activities impact the water quality. This analysis was done using Geographic Information System (GIS) and Image. GIS is a fruitful tools in building a strategic and efficient development plan spatially as well in karst area (Komac \& Urbanc, 2012) Data used in GIS were land use, Underground River, and ponors and caves distribution and the images used were SPOT 6 to detect and verify the land use.

For the GIS, data are obtained from various sources, for example Peta Rupa Bumi Indonesia (Peta RBI) from Badan Informasi Geospasial for the land use and Surface River. Geological map is obtained from Geological Agency for Gunung Sewu area.

Water Quality Analysis

Primary data collection is done through water sampling, aimed to determine water quality data through testing. Sampling points were selected based on water flow analysis of baron spring. Water samples were stored in a liter sample bottles.

Water quality status were analyzed qualitatively and quantitatively, based on the result of laboratory test of water quality for both chemical and physic parameters. Data analyzed based on Government Regulation No.82/2001, class I for the raw water.

\section{Pollution Index of Baron Spring}

Pollution index or PI is one of method of measurement water quality status to determine pollution or contamination level relative on permitted water quality parameter. This method was developed at the first place by Nemerow \& Sumitomo (1970). The classification of water quality status are based on PI score (Minister of Environment Decree No.115/2003) at Table 1.

Table 1.Pollution Index

\begin{tabular}{ll}
\hline \hline PI Score & Category \\
$0<\mathrm{PIj}<1,0$ & Good water quality \\
$1,0<\mathrm{PIj}<5,0$ & Moderately Polluted \\
$5,0<\mathrm{PIj}<10$ & Polluted \\
$\mathrm{PIj}>10$ & Extremely Polluted \\
\hline
\end{tabular}

Pollution index describe the suggestion of water quality status to determine the action or policy of the river's or water management (Sunyawati, Sunyoto, 
Kironoto, 2014; Mahyudin, Soemarno, Prayogo, 2015; Djoharam, Riani, Yani, 2018). Water quality status indicates the pollution level that showed the condition of the water in sampling time, as compared to the quality standard.

\section{Results and Discussions}

\section{A. Water Chemistry and Quality}

Water quality status were analysed as qualitatively and quantitatively, based on the result of laboratory test of water quality (obtained April $22^{\text {nd }}, 2017$ ) for both chemical and physic parameters. Data analysed based on Government Regulation No.82/2001, class I for the raw water. The result of laboratory test of Water quality can be seen at Table 2.

Table 2.Laboratory Result of Baron Spring

\begin{tabular}{|c|c|c|c|}
\hline \multicolumn{3}{|c|}{ Barong Spring } & \multirow{2}{*}{$\begin{array}{l}\text { Water } \\
\text { Standar } \\
\text { Quality }\end{array}$} \\
\hline Parameters & Unit & Value & \\
\hline \multicolumn{4}{|l|}{ Physics } \\
\hline TSS & $\mathrm{mg} / \mathrm{L}$ & $97.1^{*}$ & 50 \\
\hline TDS & $\mathrm{mg} / \mathrm{L}$ & 368 & 1000 \\
\hline \multicolumn{4}{|l|}{ Chemical } \\
\hline Nitrit (NO2-N) & $\mathrm{mg} / \mathrm{L}$ & 0.0009 & 0.06 \\
\hline Nitrat (No3-) & $\mathrm{mg} / \mathrm{L}$ & 5.542 & 10 \\
\hline Posphat (P04-P) & $\mathrm{mg} / \mathrm{L}$ & 0.025 & 0.2 \\
\hline Calcium $(\mathrm{Ca} 2+)$ & $\mathrm{mg} / \mathrm{L}$ & 84 & 150 \\
\hline $\mathrm{CaCO} 3$ & $\mathrm{mg} / \mathrm{L}$ & 84 & 500 \\
\hline Bicarbonate (HCO3-) & $\mathrm{mg} / \mathrm{L}$ & $96^{*}$ & 10 \\
\hline Oil & $\mathrm{mg} / \mathrm{L}$ & $2^{*}$ & 1 \\
\hline \multicolumn{4}{|l|}{ Biology } \\
\hline Coliform Total & $\begin{array}{l}\text { MPN/100 } \\
\mathrm{ml}\end{array}$ & $210^{*}$ & 50 \\
\hline
\end{tabular}

Total Suspended Solids (TSS) value on the sampel exceeds the parameter threshold number. It supposes to be below $50 \mathrm{mg} / \mathrm{L}$ yet it reaches 97 $\mathrm{mg} / \mathrm{L}$. TSS parameter represents suspensions in water where they are not dissolved. It can be easily observed by the turbidity of water.

Phosphate is one of the surface water quality parameter. Phosphate compounds dissolve in rocks. A movement of the earth's base will cause the rise of phosphate compound to the earth surface and surface water. Based on the results of laboratory tests, the phosphate content in baron spring samples is $0.025 \mathrm{mg} / \mathrm{L}$. Testing of phosphate aims to determine pollutant factors derived from phosphate compounds. Phosphate content is usually obtained from erosion, weathering, household and industrial waste disposal. Emissions of cleaning agents such as soap and detergents contain phosphate. In addition, industrial activities both large and small scale will increase the amount of pollutants such as phosphate.
Phosphate is one of the elements for plants breed. The phosphate contained in the soil or water will be absorbed by the roots of plants to support the plant growth process. Hence, phosphate can trigger the growth of plants. They can disrupt the flow of current or water in the river. In addition, these plants will reduce the availability of oxygen levels in the water. It disrupts the metabolic processes of bio-organism and other microorganisms in the water.

The bicarbonate content contained in water can make water become alkaline and affect the $\mathrm{pH}$ of water. Based on the results of laboratory tests, the bicarbonate content in Baron source water samples is $96 \mathrm{mg} / \mathrm{L}$. This value exceeds the standard limit for class I surface water quality. While the total content of Calcium and Hardness in the baron source water sample is $84 \mathrm{mg} / \mathrm{L}$. This value still meets the limits of class I water quality standards in Government Regulation No. 82 of 2001. According to Ruliasih (2001), hardness can be softened or eliminates / reduces hardness $\left(\mathrm{Ca}^{2+}\right.$ and $\mathrm{Mg}^{2+}$ content) in water. The methods are: heating, the process of deposition or the process of lime soda, and also ion exchange. Heating: $\mathrm{MgCO}_{3}$ salt is soluble in cold water, but the higher the water temperature, the smaller the solubility of $\mathrm{MgCO}_{3}$, even to become insoluble and can precipitate. $\mathrm{CaCO}_{3}$ salts are less solubility than $\mathrm{MgCO}_{3}$, so even in cold water so that some $\mathrm{CaCO}_{3}$ settles, in more deposition hot water. Based on these properties, the hardness produced by the $\mathrm{Mg}^{2+}$ and $\mathrm{Ca}^{2+}$ ratio can be removed by heating. It can also cause sedimentation in heating equipment.

Based on the results of laboratory tests, the total oil value in the baron spring is $2 \mathrm{mg} / \mathrm{L}$. This value has exceeded the class I water quality standard of 1 $\mathrm{mg} / \mathrm{L}$. Oil and fat content in the water will reduce the penetration of light and oxygen into the water so that it inhibits the rate of natural purification. The real impact of the presence of oil and fat on the surface of the water is the obstruction of sunlight penetration which means reducing the rate of photosynthesis in the water. The closure will also reduce oxygen free input from air to water. Lack of photosynthesis rate and oxygen input from the air will interfere with organisms in the water. Decomposition of fat and oil under conditions of lack of oxygen 2 will cause incomplete decomposition, causing a rancid odor.

Nevertheless, numbers of the alkalinity and calcium ions on the result are below the standard and relatively low. It may be caused by the hydraulic property and the water flow where the sample was taken. It was a rainy season and the water flow is high. The effect of the season on the hydraulic properties will be explained later on the next section.

The highest treat on the water quality at Baron Spring was the Coliform Total because it may yield diarrhea epidemic to the people who use the water. It exceeded far higher than the standard allowed more than 4 times folded, $210 \mathrm{MPN} / 100 \mathrm{ml}$ while the standard only allowed $50 \mathrm{MPN} / 100 \mathrm{ml}$. the coliform, 
generally is one of the threatening aspect regarding to the water quality. Poorly filtrated water and numerous sources of coliform are the main factor of the Coliform contamination. However, number of Coliform at the Baron River alters depending on the season. Coliform numbers tend to be higher on rainfall season because of the increasing washing of bacteria from the surface (Matthies \& Obst, 2011). Uncontrolled septic tank also may lead to the contamination of Coliform.

\section{B. Pollution Index}

The analysis and analysis to determine the pollution index can be seen on the Table below.

Table 3.Pollution Index at Baron Spring

\begin{tabular}{|c|c|c|c|c|c|c|}
\hline \multirow{2}{*}{ No. } & \multirow{2}{*}{ Parameter (permenkes) } & \multirow{2}{*}{ Unit } & \multicolumn{3}{|c|}{ Baron Spring } & \multirow[b]{2}{*}{ New Ci/Lij } \\
\hline & & & $\mathbf{C i}$ & Lij & Ci/Lij & \\
\hline 1 & TSS & $\mathrm{mg} / \mathrm{L}$ & 97.1 & 50 & 1.942 & 2.441 \\
\hline 2 & TDS & $\mathrm{mg} / \mathrm{L}$ & 368 & 1000 & 0.368 & 0.368 \\
\hline 3 & Nitrite (NO2-N) & $\mathrm{mg} / \mathrm{L}$ & 0.0009 & 0.06 & 0.015 & 0.015 \\
\hline 4 & $\begin{array}{l}\text { Nitrate } \\
\text { (No3-) }\end{array}$ & $\mathrm{mg} / \mathrm{L}$ & 5.542 & 10 & 0.554 & 0.554 \\
\hline 5 & Phosphate (P04-P) & $\mathrm{mg} / \mathrm{L}$ & 0.025 & 0.2 & 0.125 & 0.125 \\
\hline 6 & Calcium $(\mathrm{Ca} 2+)$ & $\mathrm{mg} / \mathrm{L}$ & 84 & 150 & 0.56 & 0.560 \\
\hline 7 & Alkalinity (CaCO3) & $\mathrm{mg} / \mathrm{L}$ & 84 & 500 & 0.168 & 0.168 \\
\hline 8 & Bicarbonate (HCO3-) & $\mathrm{mg} / \mathrm{L}$ & 96 & 10 & 9.6 & 5.911 \\
\hline 9 & Oil and Fat & $\mathrm{mg} / \mathrm{L}$ & 2 & 1 & 2 & 2.505 \\
\hline 10 & Coliform Total & MPN/100ml & 210 & 50 & 4.2 & 4.116 \\
\hline \multicolumn{2}{|c|}{$(\mathrm{Ci} / \mathrm{Lij}) \mathrm{M}$} & & & & & 4.116 \\
\hline \multicolumn{2}{|c|}{$(\mathrm{Ci} / \mathrm{Lij}) \mathrm{R}$} & & & & & 1.676 \\
\hline \multicolumn{2}{|l|}{ Pij } & & & & & 3.143 \\
\hline \multicolumn{2}{|c|}{ Category } & & & & & $\begin{array}{l}\text { Moderately } \\
\text { Polluted }\end{array}$ \\
\hline
\end{tabular}

Referring to the Minister of Environmental Decree Number 115 Year 2003, the sample of the water can be categorized as moderately polluted. Moderately polluted water could be possibly used for several utilizations. Recommendation for this level of polluted water is for the recreational purpose, fresh water aquaculture, and irrigation.

People may use this water for domestic and household purpose but with strict precautions and is not recommended. However, since the water quality in karst area is commonly poor, several treatments could be used in order to increase the quality of water hence make it more suitable for the direct usage. For the drinking water, it is obligatorily boiled first to kill the coliform bacteria. Coliform bacteria contamination may lead to digestive disease such as diarrhea. Treatment by using active carbon or arang (in the traditional terms) to absorb the pollutant is recommended considering it is easy to use (Siong, Idris, Atabaki, 2013; Fares, Aissa, Bouadi et al., 2018). Usage of carbon will decline the number of oil and fat and the suspended material in the water.

It may be not exceed the threshold yet still imperative to be considered. The amount of Calcium and the Bicarbonate ion in the water needs to get a certain attention. Long term of calcium accumulation may lead to the kidney stone which is common in the karst area. To deal with it, water is needed to be still for at least one night to let the calcium precipitated into the bottom of the water and separated from the water.

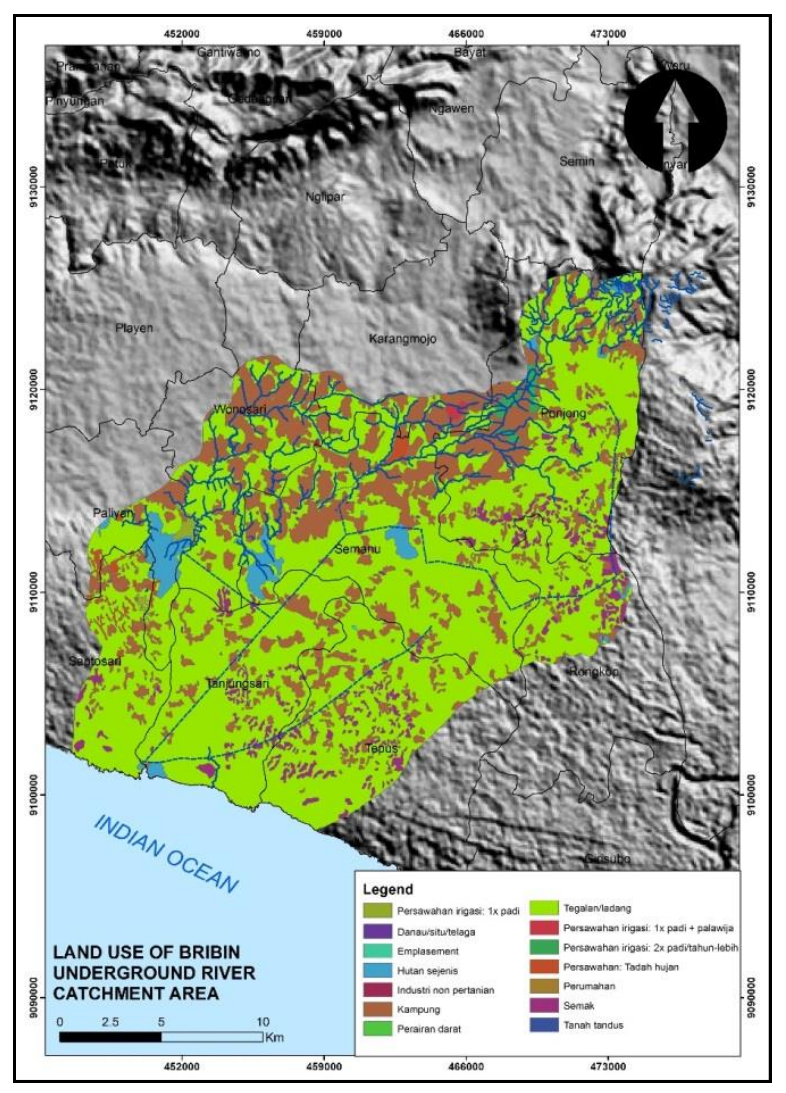

Fig. 1. Maps of Existing Land Use 
Table 4. Landuse of Study Area

\begin{tabular}{ll}
\hline \hline Land Use & Area (Ha) \\
\hline Lake/pond & 60.55 \\
Emplacement & 7.76 \\
Homogenous forest & 1173.53 \\
Non-agricultural Industry & 9.29 \\
Villages & 10544.69 \\
Land Fisheries & 50.34 \\
Rice field & 999.68 \\
Bushes & 1791.93 \\
Bare land & 29.08 \\
Field & 32953.73 \\
\hline
\end{tabular}

\section{Spatial Analysis}

The result form lab shows that the water is polluted by Coliform and high amount of bicarbonate ion, oil and fat, and the Total Suspended Solid. Sources of E. coli are likely from feces of human and animal hence, spatially there are numbers of feces sources were located at the catchment area.

There are two types of catchment area in the Bribin-Baron system. At the northern part, a surface and fluvial type is observed. Many surface river which eventually disappear into underground at the physiographic boundary. At the southern south, the water enters ground through ponor in a closed depression or doline. The difference of landform causes different land use. Where in the north, because it is topographically flatter that the southern south, it is easier to build settlement hence drives the northern side to become urban area.

\section{C.1. Urban and Settlement}

In the north side of the catchment area where most of the water comes from surface to become an underground river, situated a vast area of settlement and urban area. Urban area is one of the main sources of pollution in karst area. In terms of contamination from urban area, pollutant can be divided into "spills" or "leaks" (Vesper, Loop, \& White, 2003).

From the maps, it can be seen that feces source is land use for settlement or urban area where many septic tank and toilet in that particular area. Industrial activity and hospital in Wonosari City also contributes to the pollution on the surface water which eventually enters the sub-surface flow. It can be considered as the main source of E. coli. Because the water directly enters the ground through sinkhole, the water is poorly filtered and all of pollutants are carried away along with the water flow. Oil, as well as E. Coli, is likely produced from human activity, particularly from household. It originates from chemical compound like cooking oil from household or oil spills in the road and washed away by rainfall into sewage and eventually enters the karst conduit.

\section{C.2. Farming and Agricultural Activities}

In the southern part of the catchment area, the land use was dominated by field. This field strongly depends on rainfall. When the rain was abundant, this field is cultivated with peanut (Arachis hypogea) or rice (Oryza sativa) and when the rainfall was few, it is cultivated with cassava. Fertilizer is moderately used. At this particular area, pollutant can be washed away directly to ponor and small cave all along the catchment area.

Farming and agricultural activity may affect and pollute groundwater in karst area (Baker \& Groves, 2008). In the catchment area dry field and rice field has a very large proportion with area of $33.000 \mathrm{ha}$. It is strongly related with the high number of phosphate and nitrate in the water sample. Not only comes from the fertilizer, phosphates are also produced from decaying animal or plant. Rainfall dropping in the field washes away the decaying material from the animal and plant into groundwater. Nevertheless, the phosphate and the nitrate number still below the threshold number.

\section{Infiltration Characteristics}

Infiltration on karst area is unique because it consists by several characteristic. Based on the water flow source, karst area may have two type of source which are autogenic and allogenic. Autogenic flow happens where hydrometeorogical water or precipitation falls into a certain area of karst and directly goes underground through sinkhole or ponor. Allogenic happens where precipitation falls outside the karst area but then flows back into karst area and goes underground.

Based on the location and its infiltration characteristics, hydrological system on Karst of Gunung Sewu can be categorized into three different zone (Kusumayudha, 2002) which are: Panggang Zone, Wonosari Basin, Sadeng Zone. Panggang zone mostly consists by autogenic water infiltration and the groundwater discharges through several springs along the lithological unit of Wonosari Limestone. The spring situated around the karst either at southern side or northern side.

Sadeng zone also mostly consists by autogenic infiltration yet all the groundwater flows to southern side of the area and discharges into coastal spring or cave. Wonosari Basin Hydrological Zone comprises with both autogenic and allogenic water flows. The allogenic water comes from Wonosari Basin and supplied from old-volcanic lithology of Baturagung Ridge far north. All those water flow to the southern side of the area and released through several coastal springs including Baron Springs. 
Table 5.Comparison of Infiltration Characteristics

\begin{tabular}{llll}
\hline \hline & Panggang & $\begin{array}{l}\text { Wonosari } \\
\text { Basin }\end{array}$ & Sadeng Zone \\
\hline $\begin{array}{l}\text { Sources of } \\
\text { water }\end{array}$ & Autogenic & $\begin{array}{l}\text { Allogenic \& } \\
\text { Autogenic }\end{array}$ & Autogenic \\
Discharges & Southern and & $\begin{array}{l}\text { Southern side } \\
\text { northern side }\end{array}$ & to couthern side \\
& & zone & to cone \\
\hline
\end{tabular}

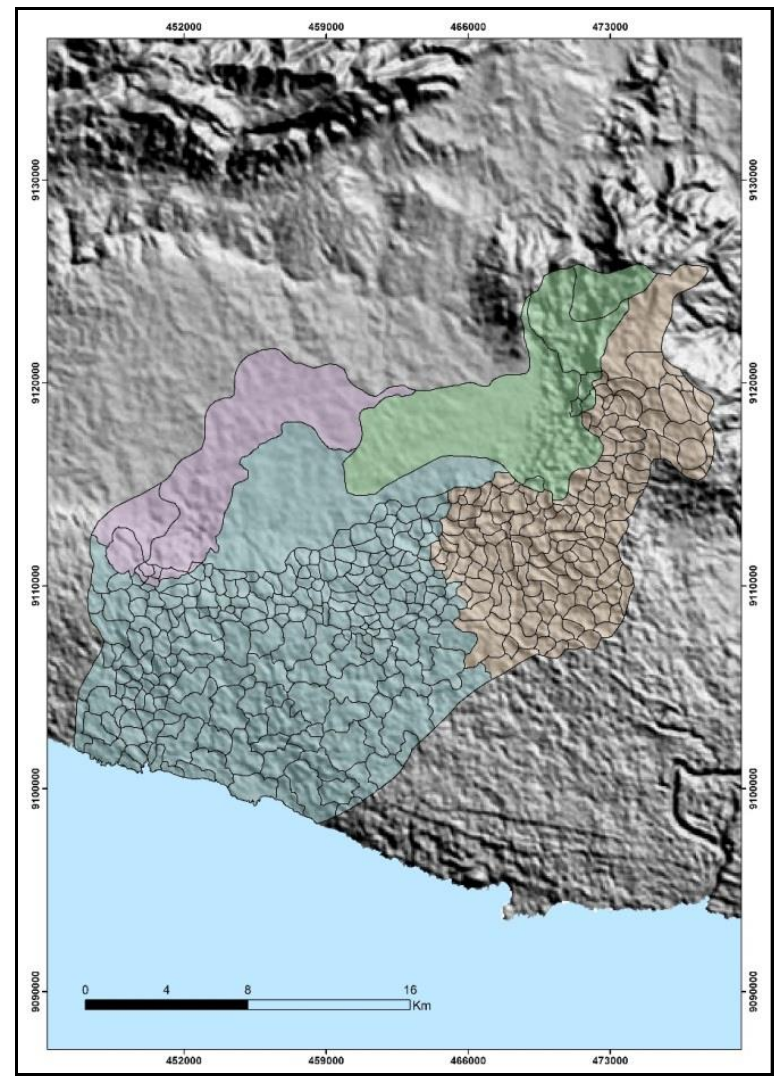

Fig. 2. Water Catchment on the Southern Side Coprised by Closed Depression

Both allogenic and autogenic water flows at Karst of Gunung Sewu has poor filtration. The autogenic which directly changes to groundwater through sinkhole has inadequate filtration because contaminants are drifted away along the water flow. Allogenic water at Karst Gunung Sewu originates from surface water and prone to contamination from the surface. No filtration happens since the surface water enters the cave directly through blind valley.

Apart from the source of water, karst infiltration can be divided into two types of diffuse and conduit water flow (White, 1988; Ford \& Williams, 2007). Diffuse and conduit water affects the velocity and transportation of contaminant on groundwater (Green, Painter, Sun et al., 2006). Contaminant tends to be transported farther and faster on conduit water flow. In diffuse water flow, contaminant has slower and lower energy hence it can be accumulated in groundwater flow.

The information of the land use can be obtained from maps. Northern side of the catchment area comprises by urban and settlement area which are the main contaminant source of E. Coli and oil. From northern side, water flow is allogenic which a huge amount of water flows directly enter underground. Nearly filtration occurs since the water flow is mostly comes from the surface water.

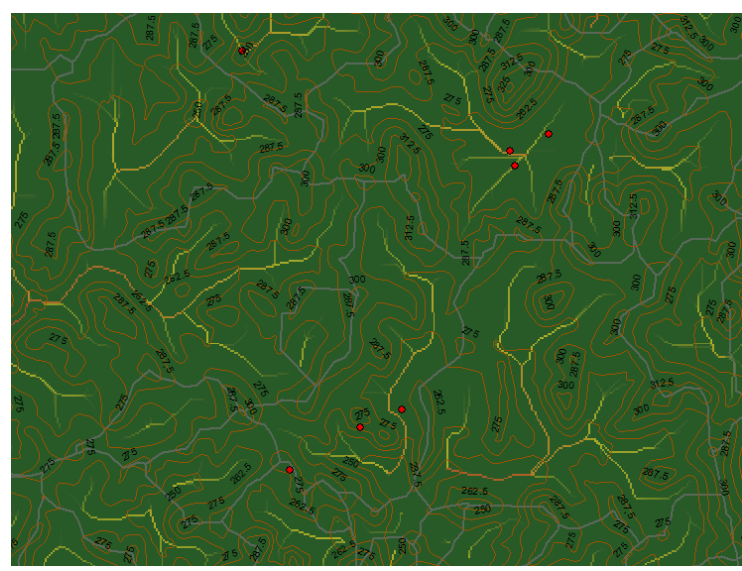

Fig. 3. Illustration of Southern Water Flows where Water only Flows inside Closed Depressions and then Dissapear Underground through Ponor or Sinkhole

In the southern part of Gunung Sewu physiography, instead of allogenic, the water flows autogenic. Autogenic water might be divided into two water flow: diffuse and conduit. Diffuse water might has filtration occurred through thin layer of terra rossa soil on the surface. However, because it has clayish texture, it also has high saturation characteristic thus only very little amount of water may be infiltrated into this layer of soil. Soil in karst also has particular role in the geochemistry and hydraulic aspect of karst water (Boschetti, Falasca, Buci, 2014). These little amounts infiltrated of water then enter the sub-surface channel through epikarst layer where diffuse infiltration happens (Klimchouk, 2004). Epikarst layer needs to be highly noticed since its role on diffuse infiltration and the storage function it has.

Conduit autogenic water flows occur when the surface water enter sub surface through sinkholes and ponors in the closed depression. These sinkholes and ponors commonly have size between $1 \mathrm{~m}$ or higher. Because of the size of the channel, water becomes turbulent characterized with high velocity and high energy of flow. Therefore, in the southern part of Gunung Sewu, the water also poorly filtrated. Filtration only happens at the thin layer of soil in the bottom of closed depression.

Hydraulic and hydrodynamical properties in karst area or karst aquifer vary through temporal changes (Prelovsek, Turk, Gabrovsek, 2008). Karst hydrology strongly depends on the amount of rainfall and the surface run-off. Interaction between the rainfall water and the porosity as the property of limestone also build the hydraulic characteristic; the hydraulic properties on dry season will be different with rainy season. Eventually, it will affect the 
material within the water like contaminant and pollutant (Epting, Page, Aukenthaler et al., 2018).

\section{E. Water Catchment Management}

Shortly, the property of the catchment area on Baron Spring can be divided into two parts: northern side and southern side. Northern side of the area comprised by urban and settlement area, has allogenic recharge and goes into subsurface through huge pocket valley like Kalisuci River, Surupan River, or Blimbing Valley. Land use in Southern Area is dominated by agriculture and village respectively. Water and run-off are recharged by autogenic through diffuse infiltration in the epikarst zone or conduit flow through sinkhole and ponor. It can be summarized on this Table below.

Table 6.Landuse Comparison Between Northern and Souther Part of Study Area

\begin{tabular}{lll}
\hline \hline & Northern Part & Southern Part \\
\hline Dominant Land Use & $\begin{array}{l}\text { Urban and } \\
\text { settlement }\end{array}$ & Agriculture \\
\multirow{2}{*}{ Recharge } & Allogenic & Autogenic \\
Channel & Conduit & Diffuse and conduit \\
Resident & Dense & Rare \\
Catchment area & Wide; Wonosari & Narrow; closed \\
& Basin & depression \\
\hline
\end{tabular}

By understanding those characteristics, several management strategies can be formulated below. Generally in northern part of the watershed, a surface hydrology management should be applied into two different approaches which are technocratic approach including waste management, septictank management, optimizing green belt at riverbank and socio-cultural approach including socialization and dissemination.

Socio-cultural approach holds a fundamental role in the watershed management. Not only affecting the water quality and quantity, socio-cultural approach also a foundation to ensure the sustainability of watershed management through participatory effort and bottom-up management model (O'Randhir, Raposa, 2014; Brombal, Niu, Pizol, et al., 2018). It is expected collaboration among stakeholder involved in applying sustainable guideline in the watershed management.

Collaborative and participatory efforts are imperative because the urban and settlement system is relatively complex with high uncertainty. Hence, in some terms, it can be considered as "wicked" (Nyerges, Ballal, Steinita, et al., 2016). The complexity emerges from its multi-sectoral dimension including geologic, economic, sociocultural, and political dimensions with multistakeholder within it. It is conceivable if every dimension and stakeholder perceive their own perception, value, and particular act in order to satisfy their own needs. Management is obligated to comprehend all of those aspects to formulate efficient and precise management guideline.

In jurisdictional aspect, framework in prevailing sustainable development is the Act Number 32 Year 2009 On Protection and Management of Environment. This act is considerably as backbone for all the environment management including watershed (Rifani, 2015). It alludes that environmental management stands on 6 pillars of planning, utilization, controlling, monitoring, maintaining, and law forcing. All of those pillars are sequentially executed to ensure the conservation works and ensure sustainable development is prevailed.

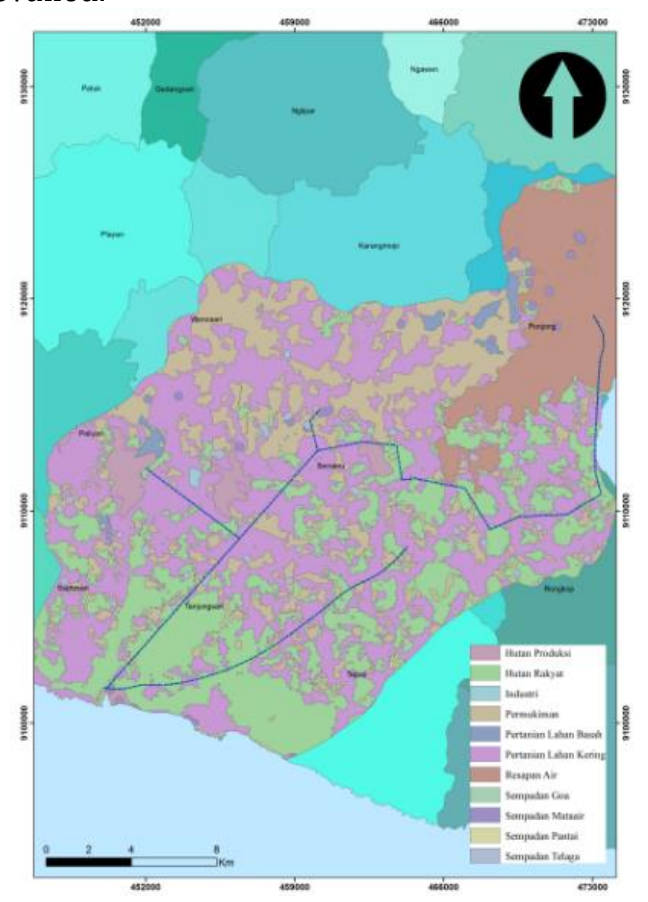

Fig. 4. Land Use Planning on the Baron Spring Catchment Area

Table 7.Planned Landuse

\begin{tabular}{lr}
\hline \multicolumn{1}{c}{ Spatial Pattern } & \multicolumn{1}{c}{ Area (Ha) } \\
\hline Production Forestry & 1039.768 \\
Social Forestry & 11979.35 \\
Industry & 49.53701 \\
Settlement & 9303.27 \\
Wetland Agriculture & 444.4222 \\
Dryland Agriculture & 18458.99 \\
Water Catchment & 5803.395 \\
Cave Buffer & 79.70451 \\
Spring Buffer & 299.2021 \\
Coastal Buffer & 35.90393 \\
Lake Buffer & 326.4795 \\
\hline
\end{tabular}

Planning and maintaining, spatially can be done by using Urban Land Use Plan (Rencana Tata Ruang Wilayah (RTRW) which put zoning based on the relation and dependency of each element to other spatially. Gunung Kidul Regency Government, in this 
case particularly Spatial Planning Agency (BAPPEDA) as the caretaker and the stakeholder which has responsibility in designing and regulating spatial planning must put the watershed management as the crucial aspect. Legally, the Urban Land Use Plan had been designed and formally prevailed at Gunung Kidul Regency Decree Number 6 Year 2011. The land use planning can be seen on Figure 4.

From the spatial planning above, it can be seen that one of the problem in terms of water quality is the inadequacy of Cave Buffer zone. It is relatively small compared to the other land use it can be hardy seen on the maps. To overcome this, it is recommended to increase the area of cave buffer zone where a more appropriate farming is practice such as decreasing number of fertilizer and utilization of filter to impede the contaminant from agricultural activity enter the water stream below the surface.

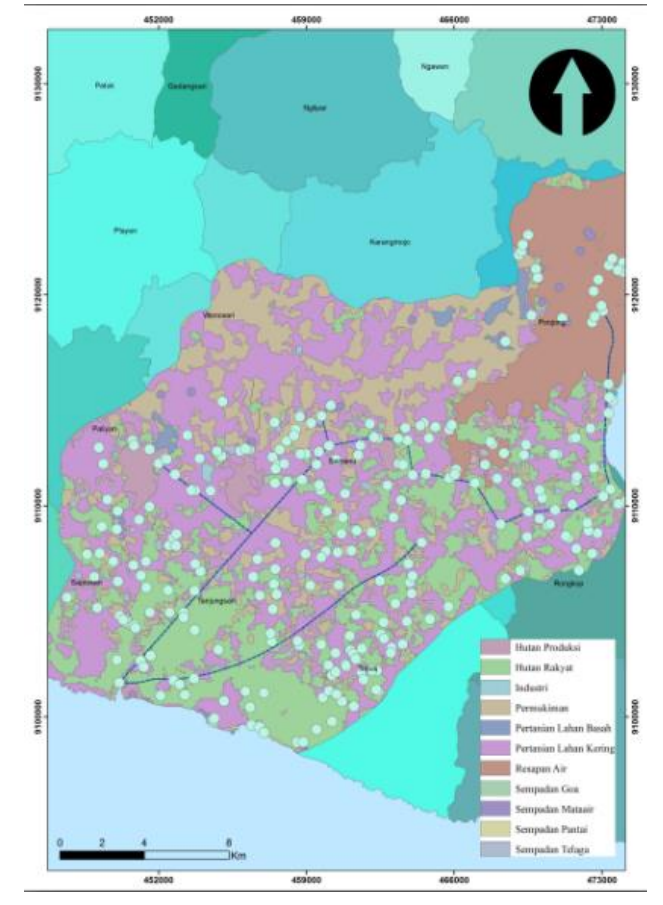

Fig. 5. Buffer Zone on The Cave

Management on the Water Catchment should incorporate the sustainable development concept. Generally, the related matter on this paper; water and urban and spatial planning are included in point 6 about Clean Water and Sanitation. Taking sustainable development into account means to embrace all of the sustainable targets into the development such as provision of sanitation facilities, integrated water resources management, and involvement of local communities.

\section{Provision of Sanitation Facilities}

Although most of the household have septic tank as the keeper of fecal waste, it is commonly founded the septic tank is not built properly. The distance between one septic tank and the other is not far enough and will lead to the lacking of pollutant and releases Coliform into the water stream. Provision of sanitation facilities is not limited only to the quantity but more importantly, the increasing quality of the facilities. Residents need to be encouraged in building proper septic tank in order to decline the number of pollutant.

\section{Involvement of Communities}

Local communities have lived along the nature far longer than other stakeholder. Their knowledge and value on water resource is very crucial in reserving water resource (Klaas, 2011). Not only because the regulator are able to obtain efficient way in managing water resource, local communities can be associated to build network among stakeholders.

3. Integrated Water Resources Management

Catchment area of Baron Springs comprised by several area with different characteristics. It is very important to comprehend all of the characteristics within a single management. As a dynamic system, every part of the catchment area is linked to each other. Management of the catchment area cannot be separated due to the inter relation of the sub-system.

4. Sinkhole's Buffer Zone

To increase filtration capacity of the sinkhole, it is important to create buffer zone where anthropogenic activities are limited. Waste and garbage in the buffer zone are also strictly managed with green belts established at the surrounding area.

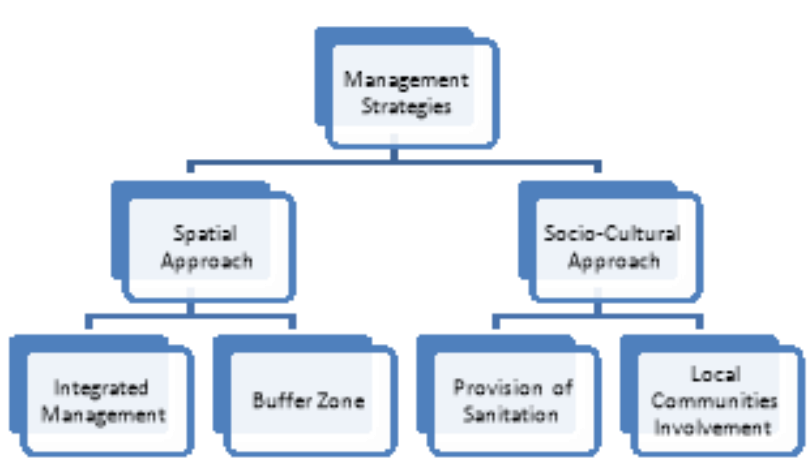

Fig. 6. Management Strategies

\section{Conclusion}

It can be concluded that water quality on the Baron Spring is moderately polluted due to the agricultural and settlement pressure on its catchment area. It's getting more severe because of the intrinsic filtration characteristic of karst landform. Filtration is poorly occurred because of the conduit channel and less diffuse infiltration. Seasonal factor also has a certain role where it increases washing from the surface.

To cope with the problem, spatial management including integrated management and designing buffer zone for the cave or sinkhole in a closed depression is important. Socio-cultural approaches like involvement of communities are also encouraged to make sure the sustainability of the project. 


\section{REFERENCES}

Haryono, E. \& Adjie, T.N. 2004. Geomorfologi dan Hidrologi Karst. Yogyakarta: Kelompok Studi Karst Fakultas Geografi UGM

Ford D \& Williams P.(2007). Karst Hydrogeology and Geomophology. England: British library

Macdonald \& Partners .1984. Greater Yogyakarta Groundwater Resources Study Vol 3C: Cave Survey.

Haryono E \& Day M. 2004. Landform differentiation within the Gunung Kidul Kegelkarst, Java, Indonesia. Journal of Cave and Karst Studies 66 (2): 62-69

Bonacci 0. 1987. Karst Hydrology: with special reference to the Dinaric Karst. Springer

Milanovic P.T.. 2005. Water Resources Engineering in Karst. CRC Press

Bakalowicz M. 2011. Management of Karst Groundwater Resurces in van Beynen P.E. (ed.) Karst Management. Springer - Verlag

Naja G M, Rivero R, Davis S.E, \& van Lent T. 2010. Hydrochemical Impacts of Limestone Rock Mining in Water Air Soil Pollution. Springer - Verlag DOI 10.1007/s11270-010-0570-2

Surono, Toha M, \& Sudarno. 1992. Peta Geologi Lembar Surakarta dan Giritontro. Pusat Penelitian dan Pengembangan Geologi

Purwanto A \& Haryono E. 2013. Analisis Hidrokemograf Airtanah Karst Sistem Sungai Bawah Tanah Bribin Kabupaten GunungKidul Jurnal Bumi Indonesisa 4 (2)

Widyastuti, M, Sudarmadji, Sutikno, \& Hendrayana H. 2012 Kerentanan Airtanah Teriiadap Pencemaran Daerah Imbuhan Ponor Di Karst Gunung Sewu (Studi Di Daerah Aliran Sungai Bawah Tanah Bribin). J. Manusia dan Lingkungan, 19 (2): 128-142

Bemmelen, R.W. 1949. The Geology of Indonesia (2 vols). The Hague: Gtv Print Office

H.D. Tjia. 2013. Morphostructural Development of Gunungsewu Karst, Jawa Island. Indonesian Journal of Geology. 8 (2): 75-88

Raras Endarto. 2015. Kajian Kerusakan Lingkungan Karst Sebagai Dasar Pelestarian Sumberdaya Air: Kasus di DAS Bribin Hulu Kabupaten Gunung Kidul Daerah Istimewa Yogyakarta. Tesis. Tidak Dipubikasikan.

Hilary Reinhart. 2015. Kajian Kerusakan Lingkungan Gua Akibat Pariwisata di Gunung Sewu UNESCO Gobal Geopark. Tesis. Tidak Dipublikasikan

Adjie T.N. 2011 Pemisahan Aliran Dasar Bagian Hulu Sungai Bribin pada Aliran Gua Gilap, di Kars Gunung Sewu, Gunung Kidul, Yogyakarta. Jurnal Geologi Indonesia 6 (3): 165-175

Pe'rez-Ceballos R., Pacheco-A' vila J., J.I. Eua'n-A' vila, and H. Hernandez-Arana H. 2012. Regionalization based on water chemistry and physicochemical traits in the ring of cenotes, Yucatan, Mexico. Journal of Cave and Karst Studies $\mathbf{7 4}$ (1): 90-102. DOI: 10.4311/2011es0222

Vysoka H, Bruthans J, K.Za k, J. Mls. 2012 Response of the karst phreatic zone to flood events in a major river (Bohemian Karst, Czech Republic) and its implication for cave genesis. Journal of Cave and Karst Studies, 74 (1): 65-81. DOI: 10.4311/2010ES0178R

Ford D.C. 2003. Perspectives in karst hydrogeology and cavern genesis. Speleogenesis and Evolution of Karst Aquifers. 1 (1): 2

Kiraly L. 2003. Karstification and Groundwater Flow. Speleogenesis and Evolution of Karst Aquifers1 (3): 2

Marína A.I, Andreo B, Mudarraa M. 2015. Vulnerability mapping and protection zoning of karst springs. Validation by multitracer tests. Science of The Total
Environment $\quad \mathbf{5 3 2} \quad(1): \quad 435-446$ https://doi.org/10.1016/i.scitotenv.2015.05.029

Marín A.I., Andreo B, Jiménez-Sánchez M, DomínguezCuesta M.J., and Meléndez-Asensio M 2012 Delineating protection areas for caves using contamination vulnerability mapping techniques: the case of Herrerías Cave, Asturias, Spain. Journal of Cave and Karst Studies 74 (1): 103-115. DOI: 10.4311/2011jcks0197

van Beynen P, Brinkmann R, \& van Beynen K 2012 A sustainability index for karst environments. Journal of Cave and Karst Studies. 74 (2): 221-234. DOI: 10.4311/2011SS0217

Brinkmann R \& Parise M. 2012. Karst Environments: Problems, Management, Human Impacts, And Sustainability An Introduction To The Special Issue. Editorial. Journal of Cave And Karst Studies $\mathbf{7 4}$ (2)Doi: 10.4311/2011jcks0253

Komac M \& Urbanc J. 2012. Assessment of spatial properties of karst areas on a regional scale using GIS and statistics - the case of Slovenia. Journal of Cave and $\begin{array}{llll}\text { Karst Studies. } & \mathbf{7 4} & \text { (3): 251-261. DOI: }\end{array}$ 10.4311/2010ES0188R

Adji, T N., Haryono E, Widyastuti M, and Sudarmadji. 2018. Identification of Contamination Recharge Area of Bribin-baron Karst Water System, Gunung Sewu, Indonesia. INA-Rxiv.. doi:10.31227/osf.io/vhwng.

Kusumayudha, S.B., 2002, Sistem Hidrogeologi Gunungsewu, Prosiding Sumberdaya Geologi Daerah Istimewa Yogyakarta dan Jawa Tengah, Ikatan Ahli Geologi Indonesia (IAGI) Pengda DIY-Jateng, p. 130 141

Epting J, Page R M, Auckenthaler A, Huggenberger P. 2018. Process-based monitoring and modeling of Karst springs - Linking intrinsic to specific vulnerability. Science of the Total Environment 625: 403-415

Zhu Z, Wang J, Hu M, Jia L. 2019. Geographical detection of groundwater pollution vulnerability and hazard in karst areas of Guangxi Province, China. Environmental Pollution 245: 627-633

Prayogo, G. Fatchurochman, H \& Wijayanti, P. 2015 Pemetaan Kerentanan Intrinsik dengan Metode EPIK sebagai Dasar Pengelolaan Daerah Tangkapan Air Matair Karst Kakap, Giriwoyo, Wonogiri. Prosiding Seminar Nasional ke-1 Pengelolaan Pesisir dan Daerah Aliran Sungai. Badan Penerbit Fakultas Geografi UGM

Pratiwi, E S. 2013. Kelemahan dan Kendala Penerapan Metode EPIK dalam Menentukan Zoanasi Kerenatnan Airtanah Intrinsik di Kawasan Karst Gunungsewu Indonesia. Seri Bunga Rampai Ekologi Lingkungan Kawasan Karst Indonesia. Deepublish. Yogyakarta

Kusumayudha, S B. 2013. Coastal Groundwater and Its Supporting Role in the Development of Gunungsewu Geopark, Java, Indonesia in Christoph Wetzelhuetter (ed.) Groundwater in the Coastal Zones of AsiaPacific. Springer-Verlag.

White, B, W.1988. Geomorphology and Hydrology of Karst Terrains. New York. Oxford University Press

Green R T, Painter S L, Sun A, Worthington S R H. 2006. Groundwater Contamination In Karst Terranes. Water, Air, and Soil Pollution: Focus 6: 157-170 DOI: 10.1007/s11267-005-9004-3

Baker T W \& Groves G C. Water Quality Impacts from Agricultural Land Use in Karst Drainage Basins of SW Kentucky and SW China. The Third Interagency Conference on Research in the Watersheds, 8-11 September 2008, Estes Park, CO 
Burri E, Castiglioni B \& Sauro U. Agriculture, Landscape And Human Impact In Some Karst Areas Of Italy. 1999. Int. J. Speleol., 28B (1/4): 33 - 54

Klimchouk A.B. 2004 Towards defining, delimiting and classifying epikarst: Its origin, processes and variants of geomorphic evolution Speleogenesis and Evolution of Karst Aquifers 2 (1):

Boschetti T., Falasca A., Bucci A., De Felice, V., Naclerio, G. and Celico F. 2014. Influence of soil on groundwater geochemistry in a carbonate aquifer, southern Italy. International Journal of Speleology 43 (1): 79-94. Tampa, FL (USA) ISSN 0392-6672 http://dx.doi.org/10.5038/1827-806X.43.1.8

Djoharama V, Rianib E, Yanic M 2018 Water Quality Analysis and Pollution Load Capacity of Pesanggrahan River, Province of DKI Jakarta Jurnal Pengelolaan Sumberdaya Alam dan Lingkungan 8 (1): 127-133

Nemerow N L, \& Sumitomo M 1970 "Benefits of Water Quality Enhancement," Report No 16110 DAJ prepared for the US Protection Agency. Syracuse University, Syracuse, NY

Saraswati S P, Sunyoto, Kironoto B A \& Hadisusanto S. 2014 Assessment of the Forms and Sensitivity of the Index Formula PI, Storet, CCME for The Determination of Water Quality Status of A Tropical Stream in Indonesia. Jurnal MANUSIA DAN LINGKUNGAN, 21 (2): 129-142. https://doi.org/10.22146/iml.18536

Siong Y. K. Idris J. \& Atabaki M M. 2013. Performance of Activated Carbon inWater Filters Water Resources

Fares R, Aissa A, Bouadi A, Lounis M. 2018. Biological Treatment of Wastewater by Addition of Activated Carbon Powder (CAP). J Waste Recycle 3 (1):2
Prelovšek M., Turk J. and Gabrovšek F. 2008. Hydrodynamic aspect of caves. International Journal of Speleology, 37 (1): 11-26. Bologna (Italy). ISSN 0392-6672.

Brombala D, Niub Y, Pizzolc L, Moriggia A, Wangf J, Crittoc A, Jiang X, Liug B, Marcomini A. 2018. A participatory sustainability assessment for integrated watershed management in urban China. Environmental Science and Policy 85 (2018): 54-63 https://doi.org/10.1016/j.envsci.2018.03.020

Randhir O T \& Raposa S. 2014. Urbanization and watershed sustainability: Collaborative simulation modeling of future development states. Journal of Hydrology 519 (2014): 1526-1536. http://dx.doi.org/10.1016/i.jhydrol.2014.08.051

Nyergesa T, Ballalb H, Steinitzb C, Canfieldd T, Rodericke M, Ritzmana J, Thanatemaneerat W. 2016. Geodesign dynamics for sustainable urban watershed development. Sustainable Cities and Society 25 (2016): 13-24

Kerstin M \& Ursula U. 2011. Concept of Appropriate Water Treatment in The Karst Region Gunung Kidul, Southern Java, Indonesia. Proceeding of Asian TransDisciplinary Karst Conference, Yogyakarta Indonesia.

Andi R. 2015. Kajian Kerusakan Lingkungan Pada Perairan Sungai Jeneberang Kabupaten Gowa Provinsi Sulawesi Selatan Akibat Aktivitas Pertambangan Pasir Sebagai Dasar Pengelolaan Lingkungan. Tesis. Tidak Dipublikasikan 